\title{
Motivation towards the foreign language (English) and regional language (Basque) in immersion schools: Does CLIL in the foreign language make a difference?
}

\begin{abstract}
Motivation to learn languages strongly correlates with language achievement, and the school context has a great influence on the motivation of young learners (YLs) (Muñoz, 2017; Ushioda, 2009). A key rationale for the implementation of CLIL programs (Coyle et al., 2010), therefore, was pupil motivation. Very few studies have measured motivation in this context, especially in primary schools (Pladevall-Ballester, 2018). Even fewer have done so in bilingual areas, where the continuation of widespread use of the regional language often depends on its presence in the school system and where CLIL reduces this presence (Lasagabaster, 2005).

To address these gaps, motivation towards the foreign language (FL), English, and the regional language, Basque, was measured in 399 YLs of English (aged 10-12) in Basque immersion schools. The learners were divided into a CLIL group $(n=230)$, with EFL and CLIL lessons, and a non-CLIL group ( $n=169)$, which received only EFL lessons.

Results showed that the CLIL learners had a more positive attitude towards English and a slightly lower motivation towards Basque. This suggests that increasing the amount of exposure to the FL via CLIL lessons improves the motivation towards English but could decrease the instrumental motivation towards the regional language.
\end{abstract}

Keywords: motivation, CLIL, EFL, young learners, immersion, Basque. 


\section{Introduction}

Two recurrent findings in empirical research on L2 motivation sustain that motivation to learn languages strongly correlates with language achievement and that children display positive attitudes towards language learning in school settings (Edelenbos et al., 2006; Mihaljević Djigunović, 2012; Murphy, 2014; Nikolov \& Mihaljević Djigunović, 2011). Research concentrating on young learners (YLs) shows that, in general, they display very positive motivational dispositions in school settings, although not all of them enjoy foreign language (FL) learning (Copland et al., 2014; Courtney et al., 2015; Muñoz, 2017) all the time (Muñoz, 2017). Research has also found that, in general, YLs' motivation to learn a FL declines as they grow older (Edelenbos et al., 2006; Mihaljević Djigunović \& Lopriore, 2011; Mihaljević Djigunović, 2012; Murphy, 2014; Nikolov \& Mihaljević Djigunović, 2011), with intrinsic motivation being more prevalent when the children are younger and instrumental motivation emerging in early adolescence (Muñoz, 2017; Nikolov, 1999). Some authors have also suggested that starting to learn a FL early in life increases the chances of children developing positive motivational dispositions, which, in turn, provides a good grounding for future language learning (Muñoz, 2017; Ushioda, 2009) and a robust rationale for introducing the FL early in schools (Fenyvesi, 2018). Unlike other more static predictors of language achievement (such as language aptitude), motivation is very dynamic, and education programs play a key role in shaping it in the case of YLs (Masgoret \& Gardner, 2003). Therefore, findings from research on YL motivation could provide important information to better understand this construct and, ultimately, to draw guidelines for improvement. Despite this, L2 motivation studies suffer from a "virtual absence of systematic research on the motivation of primary school pupils" (Boo et al., 2015, p. 156).

Motivation has constituted a solid pillar supporting the implementation of content and language integrated learning (CLIL) programs, as CLIL was claimed not only to promote higher levels of proficiency but also to boost young people's motivation to learn languages (Banegas, 2013; Doiz et al., 2014a,b). However, there has been a clear imbalance between the great bulk of research on language achievement and the more modest number of studies on motivation. In spite of the calls made by some researchers (Banegas, 2013; Gabryś-Barker \& Bielska, 2013; Lasagabaster, 2011, among others), to date very few studies have focused on motivation in CLIL contexts, and even fewer of them have been conducted in primary school settings (PladevallBallester, 2018).

So far, the investigation of motivation in the $21^{\text {st }}$ century has focused on English as the target language neglecting the study of other languages (Ushioda \& Dörnyei, 2017). The same misbalance is found in educational contexts where research on motivation has also mainly concentrated on the $\mathrm{FL}$ and, in particular, on English as a foreign language (EFL) in contexts defined as primarily monolingual (Ushioda, 2017). However, there are many bilingual areas around the world where regional minority languages are introduced into the school system by means of immersion programs, as a fundamental action to preserve and/or revitalize those languages. In these contexts, the learners, who usually speak the majority language at home, learn a regional language and a FL exclusively in the school context and, therefore, their motivation towards these languages could be greatly determined by the school program they have been enrolled in (Lasagabaster, 2005).

In recent decades regional languages have experienced a dramatic growth, and so has the number of CLIL programs. As a result, CLIL lessons have also made their way into immersion schools and several authors have warned that the attitudes towards regional languages could be affected by an increasing presence of the FL (English) (Lasagabaster, 2005), given that 
introducing CLIL lessons in English necessarily entails a decrease in the number of school hours taught through the medium of the regional language. However, research on motivation in CLIL contexts in bilingual areas, just as research on CLIL in monolingual contexts, has focused solely on the motivation towards the FL. This lack of attention to regional languages could lead to a misunderstanding of the potential and implications of a given language program. On the other hand, and from a wider perspective, placing the focus on languages other than English (e.g., regional languages) could represent a significant breakthrough in current motivation-based research (Ushioda \& Dörnyei, 2017). First, it would allow researchers to test the validity of current motivation theories, grounded in studies with English as the target language, to account for other languages (Dörnyei \& Al-Hoorie, 2017). Second, in a society with growing linguistic and cultural diversity, it would allow to explore the extent to which global English is having an impact on the motivation towards other languages. The available empirical evidence so far suggests that this impact exists and is a rather negative one (Ushioda, 2017).

To sum up, research on motivation and CLIL in primary schools is scarce and even scarcer in bilingual contexts, where school pupils' motivation to learn regional languages remains unexplored (Merino \& Lasagabaster, 2018). To address these research gaps, the present study examines the motivational dispositions of a group of 399 children learning a minority language, Basque, by means of immersion programs in primary school. The children were divided into two groups: a non-CLIL group ( $n=169$ ), in which the pupils received instruction in the $F L$, English, by means of five one-hour EFL lessons per week, and a CLIL group $(n=230)$, in which the children received five hours of EFL lessons and two hours of CLIL lessons per week. Therefore, the amount of exposure to English (regardless of instruction type) was larger in the CLIL group, in which pupils received seven lessons per week, while the pupils in the non-CLIL group only received five weekly lessons. With our study, we hope to inform L2 motivation theory by shedding more light on the motivation of YLs in particular. We also aim to offer a more complete understanding of the impact of language programs, by comparing the pupils' motivation towards the foreign language and the regional language, thus contributing to understand educational programs from a more holistic constitutive view (Ushioda, 2017). In addition to its relevance for primary school practitioners in general, our study could be of interest to teachers and other stakeholders working in bilingual contexts in other countries where regional languages are used. Finally, our study could help widen the scope of L2 motivation research by testing motivation theory with languages other than English and by shifting the focus from $L 2$ to multilingual speakers (Ushioda \& Dörnyei, 2017).

\section{Theoretical background}

\section{Motivation to learn languages: The importance of the context among YLS}

Since Gardner's early studies (Gardner \& Lambert, 1972; Gardner \& Smythe, 1975), it is clear that second language success is not only based on language aptitude but also, and to a great extent, on motivation, which is seen as the engine that maintains learners' desire, determination and effort to learn the language.

The development of $\mathrm{L} 2$ motivation theory has gone through three key historical phases (Dörnyei, 2005; Dörnyei \& Ryan, 2015; Dörnyei \& Ushioda, 2011). Initially, motivation was categorized as two main types, depending on whether it was related to the learners' personal desire to learn the language and integrate into the culture (integrative motivation) or their desire to learn it for a specific purpose such as finding a job (instrumental motivation). In a 
second phase, inspired by psychological theories of the "self" (namely Marcus \& Nurius' (1986) theory of possible selves and Higgins' (1987) theory of self-discrepancy), these two basic types of motivation gradually developed into more sophisticated and multi-faceted constructs. In a third phase, researchers emphasized the need to acknowledge the impact that factors such as the teacher, the curriculum, grades or activities exert on learners' motivational dispositions (Dörnyei, 2003; Ushioda, 2006). Thus, in order to gain a more comprehensive understanding of the complex construct of motivation Dörnyei $(2005,2009)$ formulated the theory of the L2 Motivational Self System (LMSS), which emphasized the dynamic nature of motivation and integrated three factors: Factor 1 (F1): the "ideal L2 self", which captures a person's hopes and dreams as a language learner; Factor 2 (F2) the "ought-to L2 self", which refers to the external expectations or demands that the learner feels $s /$ he is driven by (e.g. parents, significant others or teachers); and Factor 3 (F3) the L2 learning experience, which refers to the immediate learning contexts and captures the learner's attitudes towards the learning process.

In a recent comprehensive survey of 100 motivation studies, Mahmoodi and Yousefi (2021) found that the vast majority of publications had employed the LMSS. These authors argue that this has been the case thanks to the adaptability of this system to a wide variety of contexts. Thus, many empirical studies conducted in different national contexts with students in secondary school and at university have resorted to Dörnyei's $(2005,2009)$ LMSS theory and have confirmed that these three constructs largely affect both students' behavior (how much effort learners are willing to devote and how tenacious they will be) and their language outcomes (see meta-analysis in Al-Hoorie, 2019), although it should be noted that some researchers have cast doubt on the validity of the "ought-to L2 self" (see Dörnyei \& Chan, 2013; Lamb, 2012).

In the case of YLs, to the best of our knowledge, only one study has used the LMSS theory with pupils in primary school, and this study suggests that the model is also valid for this age range (Pladevall-Ballester, 2018). The inclusion of the context as a key element in the LMSS is in line with findings from studies on YLs, which reveal a strong link between motivation and the school context (Muñoz, 2017; Nikolov, 1999). For instance, Nikolov (1999) investigated EFL motivation among Hungarian schoolchildren (aged 6 to 14) and found that the most influential factors were classroom related (teacher, tasks, materials). She also identified that instrumental factors emerged in early adolescence (at ages 11 and 12) with the learners' motives becoming more utilitarian as they got older. In a more recent study, over a period of 10 years, Muñoz (2017) examined (among other factors) the motivation of Spanish learners of English (aged 616), using a mixed-methods design. Her results showed that, with age, the learners started to acknowledge the value of English (rather than of other languages) for finding employment and for integrating into the international community (even through the Internet). This same author also contributed to research into this area by identifying a clear gap between the learners' positive attitude towards English as a language and their not so positive attitude towards English as a school subject. Overall, the findings of these studies confirm the contextualized nature of young people's motivational trajectories and highlight the relevance of Dörnyei's inclusion of the context as one dimension of his LMSS theory.

\section{Motivation in CLIL contexts}

Among the benefits attributed to CLIL programs, the belief that motivation would increase was frequently brought forward (Banegas, 2013; Dalton-Puffer, 2011; Doiz et al., 2014b; Lasagabaster, 2011; Mearns, 2015; Sylvén \& Thompson, 2015). It is therefore somewhat 
surprising that very few studies to date have tested this belief empirically (Heras \& Lasagabaster, 2015), particularly with YLs in primary school settings (Pladevall-Ballester, 2018).

The vast majority of studies have been conducted in secondary school contexts, with most of the findings suggesting that motivation is, indeed, higher in CLIL contexts (Coyle et al., 2010). This has been shown mainly for English but also for other languages. For instance, Bower (2019), employing an innovative framework to capture specific aspects of motivation, reported that students (aged 11-15) learning French and German through CLIL in England displayed high levels of motivation, engagement, progress and achievement. However, learners within this setting frequently acknowledge the difficulties that CLIL entails (Bower, 2019; Coonan, 2012; Doiz et al., 2014a) and, in some cases, these perceived difficulties seem to be detrimental for language learning motivation and/or self-esteem (Cenoz \& Gorter, 2014; Seikkula-Leino, 2007). In addition, doubt has also been cast on the long-term positive motivational effects of CLIL once that type of program is no longer a novelty (Dalton-Puffer \& Smit, 2013), and a distinction has been reported between the motivation towards the $\mathrm{FL}$ and motivation towards the subject matter (Lasagabaster \& Doiz, 2017). Also, as in general research conducted in CLIL programs, several authors caution that research has been conducted in contexts where CLIL was optional, and it is not clear whether the motivation emerged from CLIL or pre-existed in the learners who chose these programs (Mearns et al., 2020). It is actually often not possible to attribute the differences identified between CLIL and non-CLIL learners to the CLIL program exclusively, as there are many variables that could be contributing to the results (Pladevall-Ballester, 2018).

Research in primary schools is very scarce and its results are rather inconclusive, with some studies pointing at a positive effect (Fernández Fontecha, 2014; Seikkula-Leino, 2007), while others did not find any differences between CLIL and non-CLIL pupils (Fernández Fontecha \& Canga Alonso, 2014). Two studies are of particular relevance here, both of them conducted in primary schools with 10 to 12 -year-olds. The first one is a study conducted by Seikkula-Leino (2007) among primary school pupils in Finland. This author found that motivation to learn a FL was higher in the CLIL groups than in the non-CLIL groups. However, this author also reported the above-mentioned detrimental effect linked to the high demands of CLIL programs, as CLIL learners rated themselves very low as English language learners. The second study was conducted in Spain by Pladevall-Ballester (2018). Over the course of a year, this author examined, among other aspects, the development of motivation in CLIL and non-CLIL learners using Dörnyei's $(2005,2009)$ LMSS theory. Her results show an advantage in the CLIL group but only in relation to the L2 learning experience dimension of motivation. In summary, these two studies reveal a modest but positive connection between motivation and CLIL programs that warrants further investigation.

\section{Motivation in minority language contexts: The case of Basque}

Regional or minority languages can be defined as languages used within a territory in which there is a dominant majority language used by a much larger number of speakers. In the EU, for example, there are over 60 regional languages, with up to 40 million speakers. In recent decades the status of regional languages in the world has enjoyed a great leap forward (Lasagabaster, 2009), as many of these languages have gained prestige, legal rights and social space. Many have witnessed an important growth in the number of speakers, mainly "new speakers" that is, people who have learnt the regional language exclusively by means of immersion or bilingual education programs (O'Rourke et al., 2015). Thus, education programs have become key in the revitalization process of regional languages. 
Unlike monolingual schools, schools in bilingual contexts need to consider (at least) three languages in their curriculum: a majority language that most speakers use at home, as well as a foreign language and a regional language that most pupils only use in the school context. In order not to be left behind in the race towards greater FL achievements, many of these schools have also started to add CLIL lessons to the regular FL lessons. This has, however, not been without controversy, as several researchers have expressed their fears that greater exposure to the FL might be detrimental for the regional language (Cenoz, 2009; Lasagabaster, 2005).

In terms of empirical research, very few studies have devoted their attention to the motivation towards the regional language of the learners enrolled in these programs (Lasagabaster, 2017). In the case of Basque, Lasagabaster (2005) conducted a study with adolescents in the Basque country, which looked at aspects that included the learners' motivation towards the regional language and the majority language (Spanish). Among other findings, his results reveal that children in Basque immersion schools hold positive attitudes towards the minority language (Lasagabaster, 2005), although some of them show a negative attitude towards the majority language, a fact which could be explained using Baker's (1992) "bunker attitude", which describes a belief that the majority language represents a threat to the survival of the regional one.

Those researchers that have paid attention to motivation towards the FL in CLIL contexts in bilingual schools with regional languages have not considered the motivation towards the regional languages (Lasagabaster, 2011; Pladevall-Ballester, 2018). One is therefore left with an incomplete picture of the impact of language programs on learner motivation and a clear gap for research that could bear enormous ecological validity. In fact, as stated in the introduction, some authors have expressed their concern regarding possible negative effects of the FL on the regional language. Baker's (1992) "bunker attitude" concept could therefore be extended in that some YLs might regard the $\mathrm{FL}$ as a threat to the regional one.

\section{The study}

\section{Research questions}

The aim of this study is to compare the motivation of pupils following EFL and CLIL programs in Basque immersion schools towards the $\mathrm{FL}$, English, and the regional language, Basque. This study presents data from a larger study on the effects of different existing language programs on the motivation and language achievements of primary school pupils in the autonomous community of Navarre (Spain), a region where Spanish is the majority language, spoken by the whole population, and Basque is a regional language, spoken by around $14 \%$ per cent of the population (Government of Navarre, 2018). In Navarre, Basque immersion schools have existed for over 40 years and the revitalization of Basque greatly depends on the "new speakers" these schools generate.

This article aims to contribute new data by investigating an under researched population in terms of motivation - primary school learners in bilingual contexts - and by including the motivation towards both the foreign language and the regional language. In the light of the literature review presented above, we framed our study within the LMSS motivation theory and analyzed our data based on the three factors defined in this theory. We repeat the factors (referred to as F1, F2 and F3) here for readers' convenience: the "ideal L2 self" (F1); the "oughtto L2 self" (F2); and the L2 learning experience (F3). Accordingly, the following research questions were formulated: 
1. Are there any differences in the motivation of CLIL and non-CLIL learners towards the foreign language (English) in F1, F2 and F3?

2. Are there any differences in the motivation of CLIL and non-CLIL learners towards the regional language (Basque) in F1, F2 and F3?

\section{Methodology}

\section{Participants}

A total of 399 primary school pupils from four different Basque-immersion schools participated in the study, 230 of which were in the CLIL group (122 girls and 108 boys) and 169 of which were in the non-CLIL group (70 girls and 99 boys). All of the children were in the fifth/sixth grade. The mean age of the pupils in the CLIL group was 10.6 years of age and the mean age of those in the non-CLIL group was 10.7. The CLIL group was made up of pupils enrolled in two schools where CLIL was compulsory for all the students. The pupils in the non-CLIL group belonged to two schools where English was taught via EFL lessons only. The four schools were state schools situated in working class neighborhoods of the same city.

The schools had agreed to participate voluntarily and informed consents of the participants' parents and tutors were obtained before data collection. The schools' teachers were in charge of the administration of the questionnaires and ensured that participants were not coerced to fill in the questionnaires. In fact, a few pupils who did not want to finish the questionnaires were allowed to do so and were excluded from the study.

As is conventionally the case in immersion school programs, all subjects were taught through the medium of Basque from Year 1 onwards (except for the four hours per week of the Spanish language subject, the majority language, starting at the age of 9). As for English, the non-CLIL schools offered pupils five EFL lessons per week from nursery school onwards, while the CLIL schools offered them five EFL lessons per week, also from nursery school onwards, and two additional hours of Arts and Crafts in English through CLIL. Taking the CLIL subject was mandatory for all the pupils, which allows us to discard the CLIL bias present in several studies conducted in optional CLIL programs (Mearns et al., 2020). The teachers in both schools were required to hold a minimum of B2 level of English and a $\mathrm{C} 1$ level of Basque and they had all followed undergraduate and/or postgraduate training programs for primary school teachers, which included training in teaching Basque, EFL and CLIL.

\section{Instrument, procedure and data analysis}

We designed an online survey with a four-point scale ("I fully agree, I somewhat agree, I somewhat disagree, I fully disagree") adapted from Pladevall-Ballester (2018), including 14 items to measure motivation towards each language, that is, the $\mathrm{FL}$ (English) and the regional language (Basque). The survey used was part of a larger study on language attainment and motivation in Navarre and it was available in Basque and Spanish (the majority language), and participants were free to choose which language they felt more comfortable with. The questionnaire was administered electronically in all four schools under the supervision of the school teachers during the months of October and November 2019.

A factor analysis of the data from the survey was performed for the two languages. It comprised principal component analysis and varimax rotation. In the case of English, the factor 
analysis accounted for $64.69 \%$ of the variance, and grouped the statements into the three factors identified within the LMSS approach, which are repeated here for readers' convenience: F1, "ideal L2 self", F2, "ought-to L2 self" and F3, "learning experience". A fourth factor (F4), which we labelled the "CLIL learning experience factor (English)" emerged, which proved to be thematically related to attitudes and motivation towards the CLIL subject in English specifically. Table 1 shows the items that correlated and loaded onto each of these factors.

Table 1. Factor analysis of items in the survey about motivation towards the foreign language (English).

\begin{tabular}{|c|c|c|c|c|}
\hline & \multicolumn{4}{|c|}{ Factors } \\
\hline & F1 & $\mathrm{F} 2$ & F3 & F4 \\
\hline $\begin{array}{l}\text { 32. I would like to speak and use English fluently and } \\
\text { effortlessly. }\end{array}$ & 0.50 & & & \\
\hline 34. I think English is a nice language. & 0.83 & & & \\
\hline 37. It is rather easy for me to learn languages. & & & 0.74 & \\
\hline 38. I like learning English. & 0.82 & & & \\
\hline 40. I would like to continue to learn English. & 0.77 & & & \\
\hline 42. I find EFL lessons really boring. & -0.68 & & & \\
\hline 45. I find CLIL lessons in English really boring. & & & & 0.84 \\
\hline 47. I think I am good at English. & & & 0.68 & \\
\hline 49. Speaking/knowing English is essential for one to find a job. & & 0.88 & & \\
\hline 52. I think CLIL lessons in English are fun. & & & & -0.48 \\
\hline 54. I think EFL lessons are fun. & 0.71 & & & \\
\hline 57. I think English will be useful for me when I grow up. & & 0.73 & & \\
\hline 59. It is difficult for me to learn languages. & & & -0.70 & \\
\hline 62. Learning English is easy. & & & 0.64 & \\
\hline 64. I feel confident when using English. & & & 0.63 & \\
\hline Total variance (\%) & 26.61 & 10.97 & 17.20 & 9.91 \\
\hline
\end{tabular}

The factor analysis for the Basque language accounted for $53.85 \%$ of the variance, and it grouped the statements into the three factors identified in the literature; that is, no factor 4 regarding the "CLIL learning experience" emerged for the Basque language (Table 2).

Table 2. Factor analysis of items in the survey about motivation towards the regional language (Basque).

\begin{tabular}{lll} 
Factors & & \\
\hline F1 & F2 & F3
\end{tabular}

33. I would like to speak and use Basque fluently and effortlessly. $\quad 0.67$

35. I think Basque is a nice language. 0.71

37. It is rather easy for me to learn languages. $\quad 0.66$

39. I like learning Basque. $\quad 0.75$

41. I would like to continue to learn Basque. $\quad 0.77$

43. I find Basque as a second language lessons really boring. $\quad-0.64$

46. I find CLIL lessons in Basque really boring.

48. I think I am good at Basque.

50. Speaking/knowing Basque is essential for one to find a job.

53. I think CLIL lessons in Basque are fun. 
59. It is difficult for me to learn languages.

63. Learning Basque is easy.

65. I feel confident when using Basque.

The comparison of the relationship between the factors and the instructional settings (CLIL and non-CLIL) was made using an analysis of variance (ANOVA). Statistical significance was fixed at $p<.05$. The results in the ANOVA tests were then interpreted by means of a chi-squared test in order to compare the CLIL and non-CLIL (EFL) groups for each specific item within each factor.

\section{Results}

This section will present the results of the comparison of the CLIL and non-CLIL groups in relation to the two research questions; that is, whether there are any differences in the motivation of CLIL and non-CLIL students towards the FL (English) and the regional minority language (Basque). Also, in Appendices 1 and 2 we present the mean values in all items for both languages to give a general idea of the pupils' scores.

\section{Motivation towards English}

In general, motivation towards English was high in both groups, with a group mean of 2.88 in the CLIL group and a group mean of 2.77 in the non-CLIL group (Appendix 1).

Regarding F1, that is, attitudes/motivation towards the "English language and the 'ideal L2 self'", mean scores reached 0.155 for the CLIL group and 0.211 for the non-CLIL group, and the differences were statistically significant, as was borne out by the ANOVA test (Table 3 ). The item-for-item chi-squared analysis revealed that the differences pointed at the CLIL group displaying a more positive attitude in this factor. Specifically, there were statistical differences in three of the items (items $34,38,54$ ). With regard to item 34 , the non-CLIL group showcased a significantly higher value in their "somewhat" disagreement with the view that "English is a nice language" (>14.2\% versus $6.1 \%$ for the CLIL group). Similarly, the non-CLIL group displayed a significantly higher level of strong disagreement on item 38 ("I like learning English"), with values of $>12.4 \%$ and $4.3 \%$ for the non-CLIL and CLIL groups respectively. The remaining statistical difference was found in item 54 , again with a higher percentage of non-CLIL students fully disagreeing with the notion that "EFL lessons are fun" (>13\% for the non-CLIL group and $5.2 \%$ for the CLIL group).

Table 3. ANOVA results. F1: English language and the "ideal L2 self".

\begin{tabular}{llllll}
\hline & $\begin{array}{l}\text { Sum of } \\
\text { squares }\end{array}$ & $\begin{array}{l}\text { Degrees of } \\
\text { freedom }\end{array}$ & $\begin{array}{l}\text { Mean } \\
\text { squares }\end{array}$ & F-test & Significance \\
\hline Intergroup & 13.018 & 1 & 13.018 & 13.425 & 0.0007653 \\
Within-group & 384.982 & 397 & 0.970 & & \\
Total & 398.000 & 398 & & & \\
\hline
\end{tabular}


The ANOVA test did not reveal significant differences in F2 - that is, on the "ought-to L2 self" - between the CLIL (mean score 0.051 ) and non-CLIL (mean score 0.070 ) groups (Table 4). Likewise, the chi-squared analysis did not identify any significant differences between groups in either of the items in F2. Both groups displayed general agreement on the notion that "Speaking/knowing English is essential for one to find a job" (item 49) and on item 57 ("I think English will be useful for me when I grow up"), with mean percentages surpassing $80 \%$ in both groups for each item.

Table 4. ANOVA results. F2: Usefulness of learning English and the "ought-to L2 self".

\begin{tabular}{llllll}
\hline & $\begin{array}{l}\text { Sum of } \\
\text { squares }\end{array}$ & $\begin{array}{l}\text { Degrees of } \\
\text { freedom }\end{array}$ & $\begin{array}{l}\text { Mean } \\
\text { squares }\end{array}$ & F-test & Significance \\
\hline Intergroup & 1.421 & 1 & 1.421 & 1.422 & 0.4634990 \\
Within-group & 396.579 & 397 & 0.999 & & \\
Total & 398.000 & 398 & & & \\
\hline
\end{tabular}

Differences on F3 (the learning experience (English)") reached statistical significance, and mean scores were 0.114 for the CLIL group and 0.155 for the non-CLIL group (Table 5). However, the chi-squared analysis did not yield significant differences on individual items, so the interpretation of such difference is somewhat fuzzy. Some of the most noticeable differences lay in item 47 ("I think I am good at English") in which there were higher mean percentages of agreement for the CLIL group (70.4\%) than the non-CLIL group (61.5\%). Conversely, item 37 ("It is rather easy for me to learn languages") revealed $73.9 \%$ and $84 \%$ agreement rates for the CLIL and non-CLIL respectively. This was confirmed by item 59 ("It is difficult for me to learn languages"), with a $41.7 \%$ agreement rate for the CLIL group as opposed to $33.1 \%$ for the non-CLIL group.

Table 5. ANOVA results. F3: The learning experience (English).

\begin{tabular}{llllll}
\hline & $\begin{array}{l}\text { Sum of } \\
\text { squares }\end{array}$ & $\begin{array}{l}\text { Degrees of } \\
\text { freedom }\end{array}$ & $\begin{array}{l}\text { Mean } \\
\text { squares }\end{array}$ & F-test & Significance \\
\hline Intergroup & 7.008 & 1 & 7.008 & 7.115 & 0.0156638 \\
Within-group & 390.993 & 397 & 0.985 & & \\
Total & 398.000 & 398 & & & \\
\hline
\end{tabular}

Although no comparison can be drawn on F4 (the "CLIL learning experience"), the results for the CLIL group indicated that $63.9 \%$ of learners disagreed with the statement that CLIL lessons in English are really boring (item 45), a stance which was ratified by a $58.7 \%$ support that CLIL lessons in English are fun (item 52).

Finally, it is worth mentioning that, in spite of the differences described above, the mean values obtained in all items showed that motivation towards the English was remarkably high (see Appendix 1).

\section{Motivation towards Basque}


The motivation towards Basque in both groups was generally high, with a group mean of 3.12 in the CLIL group and 3.08 in the non-CLIL group (Appendix 2).

Mean scores for the F1 ("Basque language and the 'ideal L2 self') were 0.117 for the CLIL group and 0.036 for the non-CLIL group, and no statistically significant differences between groups were observed in the ANOVA test (Table 6). However, the item-for-item chi-squared analysis revealed a statistically significant difference on item 35 specifically, in which $3 \%$ of the non-CLIL students somewhat disagreed with the view that "Basque is a nice language" (compared to $0 \%$ in the CLIL group).

Table 6. ANOVA results. F1: Basque language and the "ideal L2 self".

\begin{tabular}{llllll}
\hline & $\begin{array}{l}\text { Sum of } \\
\text { squares }\end{array}$ & $\begin{array}{l}\text { Degrees of } \\
\text { freedom }\end{array}$ & $\begin{array}{l}\text { Mean } \\
\text { squares }\end{array}$ & F-test & Significance \\
\hline Intergroup & 1.843 & 1 & 1.843 & 1.875 & 0.3362102 \\
Within-group & 312.533 & 318 & 0.983 & & \\
Total & 314.376 & 319 & & & \\
\hline
\end{tabular}

The ANOVA test yielded significantly different results regarding F2 (the "Usefulness of learning English and the 'ought-to L2 self'"), with mean scores of 0.134 for the CLIL group and 0.183 for the non-CLIL group (Table 7). The chi-squared analysis showed a statistically significant difference between the CLIL and non-CLIL groups on item 50 ("Speaking/knowing Basque is essential for one to find a job"), with a percentage of $23 \%$ (CLIL) and $10.1 \%$ (non-CLIL) of participants somewhat disagreeing with the statement, although overall agreement rates (i.e. "fully agree" and "somewhat agree") showed high values in both groups (70.9\% for the CLIL group and $84.3 \%$ for the non-CLIL group). This difference could be related to the notion that, as students start to gradually acknowledge the value of English to find employment (Muñoz, 2017), they might be doing so at the expense of downplaying the importance of other languages, in this case Basque.

Table 7. ANOVA results. F2: Usefulness of learning Basque and the "ought-to L2 self".

\begin{tabular}{llllll}
\hline & $\begin{array}{l}\text { Sum of } \\
\text { squares }\end{array}$ & $\begin{array}{l}\text { Degrees of } \\
\text { freedom }\end{array}$ & $\begin{array}{l}\text { Mean } \\
\text { squares }\end{array}$ & F-test & Significance \\
\hline Intergroup & 9.751 & 1 & 9.751 & 9.971 & 0.0037736 \\
Within-group & 387.249 & 396 & 0.978 & & \\
Total & 397.000 & 397 & & & \\
\hline
\end{tabular}

Results for F3 (the "Learning experience (Basque)") in the ANOVA test revealed nonsignificant differences, and mean scores were 0.065 (CLIL group) and 0.088 (non-CLIL group) (Table 8). The chi-squared analysis did not identify any significant difference between groups in any of the items, and both groups coincided on their view that they were "good at Basque" (item 48, with $93.5 \%$ and $94.8 \%$ agreement in the EFL and CLIL groups respectively) and on their view that "learning Basque is easy" (item 63, with $88.7 \%, 88.3 \%$ for the EFL and CLIL groups respectively).

Table 8. ANOVA results. F3: The learning experience (Basque).

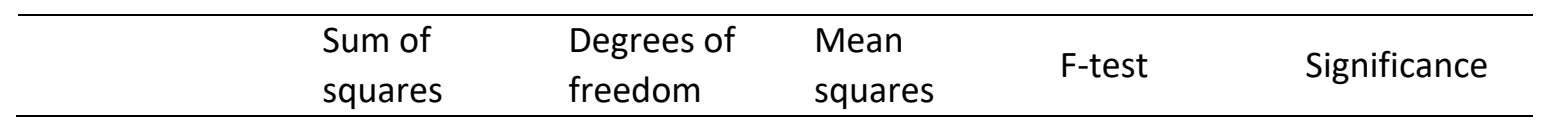




\begin{tabular}{llllll}
\hline Intergroup & 2.269 & 1 & 2.269 & 2.276 & 0.2557225 \\
Within-group & 394.731 & 396 & 0.997 & & \\
Total & 397.000 & 397 & & & \\
\hline
\end{tabular}

It should be noted, again, that the mean values in all items revealed very high motivation rates towards Basque (see Appendix 2).

Finally, the validity of the results for both languages presented above was supported by the results of ANOVA tests comparing socioeconomic status, in which no significant differences between the CLIL and non-CLIL were found in any factor, with significance levels at 1.97 (F1), $0.78(\mathrm{~F} 2)$ and $0.41(\mathrm{~F} 3)$.

\section{Discussion and conclusions}

The present study set out to examine whether there were any differences between CLIL and non-CLIL primary school learners towards the FL (English) and the regional language (Basque) in the three factors present in the LMSS described in the literature. The results provided evidence suggestive of substantial differences in the way the implementation of a CLIL program in English affects learners' motivation towards the $\mathrm{FL}$ and the regional language.

With reference to the first research question, statistically significant differences between the CLIL and non-CLIL groups in their attitude towards the FL (English) were revealed on factors 1 ("English language and the "ideal L2 self'") and 3 (the "Learning experience (English)"), while no significant differences were found on F2 (the "Usefulness of learning English and the 'ought-to L2 self'"). Regarding F1, CLIL learners clearly reported a more positive attitude towards English than the non-CLIL group, including significant differences on their perception of English as a beautiful language (item 34), their enjoyment while learning the language (item 38) and their view of the EFL subject as fun (item 54). In relation to F3, CLIL learners also displayed an advantage over non-CLIL leaners; however, no significant differences on individual items were found, and the interpretation of the overall difference in this factor is more complex. The CLIL group rated themselves higher in the perception of their own performance as language learners in English but lower than the non-CLIL group in their perception of the difficulties language learning entails, suggesting that CLIL learners are perhaps more aware of the complex process of acquiring a language. Interestingly, F3, that is, the "Learning experience (English)" was also the only factor in which significant differences were reported in a similar previous study (Pladevall-Ballester, 2018), with YLs in a similar context (Spain), and also indicating a positive effect for the CLIL group. This coincidence supports the notion that motivation during childhood seems to hinge, to a large degree, on the educational context (Nikolov, 1999; Muñoz, 2017; Ushioda, 2009).

The results for the second research question, that is, the motivation/attitude towards the regional minority language (Basque), are markedly different to the results towards English, since the only statistically significant difference was revealed on F2 (the "Usefulness of learning Basque and the 'ought-to L2 self'"), while no significant differences were found on F1 ("Basque language and the 'ideal L2 self'") and F3 (the "Learning experience (Basque)"). Specifically, regarding F2, the CLIL and non-CLIL groups differed significantly on their slight disagreement with the notion that knowing Basque is essential to find a job (item 50), with the CLIL group displaying a significantly higher percentage. Curiously, the only remaining significant difference was spotted on F1 (item 35), in which non-CLIL learners displayed a comparatively higher 
percentage $(3 \%)$ of learners somewhat disagreeing with their perception of Basque as a nice language (compared with none in the CLIL group).

In summary, this study has provided evidence that the instructional setting (CLIL vs. nonCLIL) appears to affect YLs' motivation towards the foreign language and regional language in different ways, and to different extents. Differences in motivation towards the FL (English) were more numerous and significant, and, in general terms, revealed higher motivational levels for the CLIL group. Differences in motivation towards the regional language were more limited and seemed to hinge on the learners' view on the importance of the regional language in their future professional life. It could be hypothesized that the significantly lower importance attributed to Basque in this respect might have been overshadowed by the instrumental power of English as a motivational force in a globalised world where knowing English is frequently associated with concepts such as necessity, utility, advantage or power (Ushioda, 2017). This finding is in line with previous research showing how students acknowledge the instrumental value of English (Muñoz, 2017) and with those warning about a possible negative effect of the international language on the regional one (Cenoz, 2009; Lasagabaster, 2005) as well as on other languages in general (foreign, regional, minority or heritage) (Ushioda, 2017), yet more studies are needed to address this aspect specifically. However, the fact that non-CLIL students also perceived Basque as being less of a beautiful language than the CLIL group did suggests that the relationship between the language of immersion and motivation might not just be limited to the amount of exposure but also to additional mediating factors.

Another important difference was found while conducting our factor analysis. The items loaded onto four factors in the case of English but onto three in the case of Basque, the fourth one being the "CLIL learning experience factor (English)" as different from the "EFL learning experience". On the one hand, this reveals a difference in the perception of learners' motivation towards the foreign language and regional minority language; that is, while the learners perceived a clear distinction between the lessons where English was taught as a subject and those where English was used to teach content, they did not perceive this difference in the case of Basque. The pupils' more homogeneous perception of content lessons in Basque and Basque as a subject could probably be linked to their instructional setting (Basque immersion), as well as to the sociopolitical and educational environment (Ushioda, 2017). Further research into the educational and social context and the methodological implementation of both languages could probably help interpret this finding. On the other hand, the emergence of a separate factor for CLIL lessons in English is a finding well worth further investigation, as it could help refine the LMMS theory.

Globally, our scores were generally high and, therefore, our study also supports previous findings that (a) children's motivation towards language learning is high in general (Copland et al., 2014; Courtney et al., 2015; Muñoz, 2017), (b) learner perceptions of instrumental motivation in this age group are already present (Muñoz, 2017; Nikolov, 1999), and (c) children in bilingual schools have a positive attitude/motivation towards the regional language (Lasagabaster, 2005).

In sum, our study highlights the power of the school program to shape motivation towards language learning and suggests that the inclusion of English through CLIL in bilingual contexts could benefit YLs' attitude/motivation towards English. At the same time, though, the power of this international language could negatively affect the learners' perception of the instrumental value of the regional language. All this should be taken into account when 
implementing CLIL in bilingual programs and, above all, more research should be conducted to confirm, disprove or qualify these findings in other contexts.

To conclude, this study is not without limitations. Firstly, and regarding the methodology employed, we did not compare the scores obtained in each of the factors integrated in Dörnyei's $(2005,2009)$ LMSS theory. This could be done in future research, firstly to test whether one of the factors obtains significantly higher scores than the others, and secondly to test previous findings like the one reported in Muñoz (2017) about learners loving English (F1) but not English lessons (F3). In line with this, our study could have benefitted from the employment of innovative methods to look into very specific motivational dynamics (Bower, 2019; Mahmoodi \& Yousefi, 2021). Second, the participants went to four different schools and, although they were similar in many respects, the influence of specific school-related factors, such as the teachers or the classroom practices, could not be controlled. Second, as the pupils filled in both questionnaires on the same day they might have felt that they were being asked to compare the languages. The surveys could be administered in separate sessions to avoid comparisons and to obtain a more independent assessment of each language. Third, in our study we are comparing learners who receive different amounts of total exposure to English (seven vs. five weekly hours). While this is a somewhat inevitable effect of the implementation of CLIL, which is normally added to the regular EFL lessons, it would be extremely interesting to compare students with similar amounts of exposure to English and who only differed in the type of lessons they receive (CLIL vs. EFL). To finish, the CLIL learners in our study only receive two CLIL lessons per week of only one subject (Arts and Crafts). Further studies should investigate the impact of different school subjects (Pladevall-Ballester, 2018) and compare groups of learners with different amounts of exposure to CLIL lessons to see if, as our results seem to suggest, the more the merrier.

\section{Acknowledgements}

Withheld till acceptance

\section{Funding information}

Withheld till acceptance

\section{References}

Al-Hoorie, A. H. (2019). The L2 motivational self-system: A meta-analysis. Studies in Second Language Learning and Teaching, 8(4), 721-754. https://doi.org/10.14746/ss/lt.2018.8.4.2

Baker, C. (1992). Attitudes and Language (Vol. 83). Clevedon, UK: Multilingual Matters.

Banegas, D. (2013). The integration of content and language as a driving force in the EFL lesson. In E. Ushioda (Ed.), International perspectives on motivation: Language learning and professional challenges (pp. 82-97). Basingstoke, UK: Palgrave Macmillan.

Boo, Z., Dörnyei, Z., \& Ryan, S. (2015). L2 motivation research 2005-2014: Understanding a publication surge and a changing landscape. System, 55, 145-157. https://doi.org/10.1016/j.system.2015.10.006 
Bower, K. (2019). Explaining motivation in language learning: a framework for evaluation and research. The Language Learning Journal, 47(5), 558-574. https://doi.org/10.1080/09571736.2017.1321035

Cenoz, J. (2009). Towards multilingual education: Basque educational research from an international perspective (Vol. 72). Bristol, UK: Multilingual Matters.

Cenoz, J., \& Gorter, D. (2014). Focus on multilingualism as an approach in educational contexts. In In A. Blackledge \& A. Creese (Eds.), Heteroglossia as practice and pedagogy (pp. 239-254). Dordrecht, Netherlands: Springer.

Copland, F., Garton, S., \& Burns, A. (2014). Challenges in teaching English to young learners. Global perspectives and local realities. TESOL Quarterly, 48(4), 738-762. https://doi.org/10.1002/tesq.148

Courtney, L., Graham, S., Tonkyn, A., \& Marinis, T. (2017). Individual differences in early language learning: A study of English learners of French. Applied Linguistics, 38(6), 824-847. https://doi.org/10.1093/applin/amv071

Coyle, D., Hood, P., \& Marsh, D. (2010). CLIL: Content and Language Integrated Learning. Cambridge: Cambridge University Press.

Dalton-Puffer, C. (2011). Content-and-language integrated learning: from practice to principles? Annual Review of Applied Linguistics, 31, 182-204. https://doi.org/10.1017/s0267190511000092

Dalton-Puffer, C., \& Smit, U. (2013). Content and language integrated learning: A research agenda. Language Teaching, 46(4), 545-559. https://doi.org/10.1017/s0261444813000256

Doiz, A., Lasagabaster, D., \& Sierra, J.M. (2014a). Giving voice to the students: What (de)motivates them in CLIL classes? In D. Lasagabaster, A. Doiz, \& J.M. Sierra (Eds), Motivation and foreign language learning: From theory to practice (pp. 117-138). Amsterdam, Netherlands: John Benjamins.

Doiz, A., Lasagabaster, D., \& Sierra, J.M. (2014b) CLIL and motivation: The effect of individual and contextual variables. The Language Learning Journal, 42, 209-224. https://doi.org/10.1080/09571736.2014.889508

Dörnyei, Z. (2003). Attitudes, orientations and motivations in language learning: Advances in theory, research, and applications. Language Learning, 53, 3-32. https://doi.org/10.1111/1467-9922.53222

Dörnyei, Z. (2005). The psychology of the language learner: Individual differences in second language acquisition. Mahwah, NJ: Lawrence Erlbaum. https://doi.org/10.1017/s0272263107310061

Dörnyei, Z. (2009). The L2 motivational self system. In Z. Dörnyei, \& E. Ushioda (Eds), Motivation, language identity and the L2 self (pp. 92-142). Bristol, UK: Multilingual Matters. 
Dörnyei, Z., \& Chan, L. (2013). Motivation and vision: An analysis of future L2 self images, sensory styles, and imagery capacity across two target languages. Language Learning, 63(3), 437-462. https://doi.org/10.1111/lang.12005

Dörnyei, Z., \& Ryan, S. (2015). The psychology of the language learner revisited. New York, USA: Routledge. https://doi.org/10.4324/9781315779553

Dörnyei, Z., \& Al-Hoorie, A. H. (2017). The motivational foundation of learning languages other than global English: Theoretical issues and research directions. The Modern Language Journal, 101(3), 455-468. https://doi.org/10.1111/modl.12408

Dörnyei, Z., \& Ushioda, E. (2011). Teaching and researching motivation (2nd ed.). Harlow, UK: Longman. https://doi.org/10.4324/9781351006743

Edelenbos, P., Johnstone, R., \& Kubanek, A. (2006). The main pedagogical principles underlying the teaching of languages to very young learners. Brussels, Belgium: European Commission, Education and Culture, Culture and Communication Multilingualism Policy.

Fernández Fontecha, A. (2014). Receptive vocabulary knowledge and motivation in CLIL and EFL. Revista de Lingüística y Lenguas Aplicadas, 9, 23-32.

https://doi.org/10.4995/rlyla.2014.2077

Fernández Fontecha, A., \& Cangas Alonso, A. (2014). A preliminary study on motivation and gender in CLIL and non-CLIL types of instruction. International Journal of English Studies, 14(1), 21-36. https://doi.org/10.6018/ijes/14/1/156681

Gabryś-Barker, D., \& Bielska, J. (2013). The affective dimension in second language acquisition. Bristol, UK: Multilingual Matters. https://doi.org/10.21832/9781847699695

Gardner, R. C., \& Lambert, W. E. (1972). Attitudes and motivation in second language learning (Vol. 786). Newbury: Rowley.

Gardner, R. C., \& Smythe, P. C. (1975). Motivation and second-language acquisition. Canadian Modern Language Review, 31(3), 218-233.

Gobierno de Navarra. (2018). Datos sociolingüísticos de Navarra. https://gobiernoabierto.navarra.es/sites/default/files/estudio soiolinguistico 2018.pd $\underline{f}$

Heras, A., \& Lasagabaster, D. (2015). The impact of CLIL on affective factors and vocabulary learning. Language Teaching Research, 19(1), 70-88. https://doi.org/10.1177/1362168814541736

Higgins, E. T. (1987). Self-discrepancy: A theory relating self and affect. Psychological review, 94(3), 319-340. https://doi.org/10.1037/0033-295x.94.3.319

Lamb, M. (2012) A self-system perspective on young adolescents' motivation to learn English in urban and rural settings. Language Learning, 62, 997-1023. https://doi.org/10.1111/i.1467-9922.2012.00719.x 
Lasagabaster, D. (2005). Attitudes towards Basque, Spanish and English: An analysis of the most influential variables. Journal of Multilingual and Multicultural Development, 26(4), 296-316. https://doi.org/10.1080/01434630508669084

Lasagabaster, D. (2009). The implementation of CLIL and attitudes towards trilingualism. International Journal of Applied Linguistics, 157(1), 23-43. https://doi.org/10.2143/ITL.157.0.2042586

Lasagabaster, D. (2011). English achievement and student motivation in CLIL and EFL settings. Innovation in Language Learning and Teaching, 5, 3-18. https://doi.org/10.1080/17501229.2010.519030

Lasagabaster, D., \& Doiz, A. (2017). A longitudinal study on the impact of CLIL on affective factors. Applied Linguistics, 38(5), 688-712. https://doi.org/10.1093/applin/amv059

Mahmoodi, M. H., \& Yousefi, M. (2021). Second language motivation research 2010-2019: a synthetic exploration. The Language Learning Journal, 1-24. https://doi.org/10.1080/09571736.2020.1869809

Markus, H., \& Nurius, P. (1986). Possible selves. American Psychologist, 41(9), 954-969. https://doi.org/10.1037/0003-066x.41.9.954

Masgoret, A. M., \& Gardner, R. C. (2003). Attitudes, motivation, and second language learning: A meta-analysis of studies conducted by Gardner and associates. Language Learning, 53(1), 167-210. https://doi.org/10.1111/1467-9922.00227

Mearns, T. (2015). Chicken, egg or a bit of both? Motivation in bilingual education (TTO) in the Netherlands. Unpublished Doctoral Dissertation. University of Aberdeen, UK, and Universiteit Utrecht, The Netherlands.

Mearns, T., de Graaff, R., \& Coyle, D. (2020). Motivation for or from bilingual education? A comparative study of learner views in the Netherlands. International Journal of Bilingual Education and Bilingualism, 23(6), 724-737. https://doi.org/10.1080/13670050.2017.1405906

Merino, J. A., \& Lasagabaster, D (2018) CLIL as a way to multilingualism. International Journal of Bilingual Education and Bilingualism, 21, 1, 79-92. https://doi.org /10.1080/13670050.2015.1128386

Mihaljević Djigunović, J. (2012). Attitudes and motivation in early foreign language learning. CEPS Journal, 2, 55-74.

MihaljevićDjigunović, J., \& Lopriore, L. (2011). The learner: Do individual differences matter? In J. Enever (Ed.), ELLiE: Early Language Learning in Europe (pp. 43-60). London, UK: BritishCouncil.

Muñoz, C. (2017). Tracing trajectories of young learners: Ten years of school English learning. Annual Review of Applied Linguistics, 37, 168-184. https://doi.org/10.1017/s0267190517000095 
Murphy, V. A. (2014). Second language learning in the early school years: Trends and contexts. Oxford, USA: Oxford University Press. https://doi.org/10.1111/ijal.12116

Nikolov, M. (1999). 'Why do you learn English?' 'Because the teacher is short'. A study of Hungarian children's foreign language learning motivation. Language Teaching Research, 3(1), 33-56. https://doi.org/10.1191/136216899670790538

Nikolov, M., \& Djigunovic, J. M. (2011). All shades of every color: An overview of early teaching and learning of foreign languages. Annual Review of Applied Linguistics, 31, 95-119. https://doi.org/10.1017/s0267190511000183

O'Rourke, B., Pujolar, J., \& Ramallo, F. (2015). New speakers of minority languages: the challenging opportunity-Foreword. International Journal of the Sociology of Language, 231, 1-20. https://doi.org/10.1515/ijsl-2014-0029

Pladevall-Ballester, E. (2018). A longitudinal study of primary school EFL learning motivation in CLIL and non-CLIL settings. Language Teaching Research, 23(6), 765-786. https://doi.org/10.1177/1362168818765877

Seikkula-Leino, J. (2007). CLIL learning: Achievement levels and affective factors. Language and Education, 21(4), 328-341. https://doi.org/10.2167/le635.0

Sýlven, L.K., \& Thompson, A.S. (2015). Language learning motivation and CLIL: Is there a connection? Journal of Immersion and Content-Based Language Education, 3, 28-50. https://doi.org/10.1075/iicb.3.1.02syl

Ushioda, E. (2006). Language motivation in a reconfigured Europe: Access, identity, autonomy. Journal of Multilingual and Multicultural Development, 27(2), 148-161. https://doi.org/10.1080/01434630608668545

Ushioda, E. (2009). A person-in-context relational view of emergent motivation, self and identity. In Z. Dornyei \& E. Ushioda (Eds.), Motivation, language identity and the L2 self (pp. 215-228). Bristol, UK: Multilingual Matters.

Ushioda, E. (2017). The impact of global English on motivation to learn other languages: Toward an ideal multilingual self. Modern Language Journal, 101(3), 469-482. https://doi.org/10.1111/modl.12413

Ushioda, E., \& Dörnyei, Z. (2017). Beyond global English: Motivation to learn languages in a multicultural world: Introduction to the special issue. The Modern Language Journal, 101(3), 451-454. 
Appendix 1. Mean values. Survey about English.

\begin{tabular}{lll} 
& \multicolumn{2}{l}{ Mean values } \\
\cline { 2 - 3 } & CLIL & Non-CLIL \\
\hline 32. I would like to speak and use English fluently and effortlessly. & 3.36 & 3.18 \\
34. I think English is a nice language. & 3.30 & 3.14 \\
37. It is rather easy for me to learn languages. & 2.99 & 2.95 \\
38. I like learning English. & 3.10 & 2.89 \\
40. I would like to continue to learn English. & 3.26 & 3.14 \\
42. I find EFL lessons really boring. & 2.16 & 2.18 \\
45. I find English CLIL lessons really boring. & 2.23 & 2.11 \\
47. I think I am good at English. & 2.84 & 2.60 \\
49. Speaking/knowing English is essential for one to find a job. & 3.32 & 3.21 \\
52. I think CLIL lessons in English are fun. & 2.65 & 2.73 \\
54. I think EFL lessons are fun. & 2.95 & 2.81 \\
57. I think English will be useful for me when I grow up. & 3.48 & 3.36 \\
59. It is difficult for me to learn languages. & 2.23 & 2.34 \\
62. Learning English is easy. & 2.66 & 2.41 \\
64. I feel confident when using English. & 2.81 & 2.54 \\
& 2.88 & 2.77 \\
\hline
\end{tabular}

Values: 4: 'I fully agree'; 3: 'I somewhat agree'; 2: 'I somewhat disagree'; 1: 'I fully disagree'.

Appendix 2. Mean values. Survey about Basque.

\begin{tabular}{lll} 
& \multicolumn{2}{l}{ Mean values } \\
\cline { 2 - 3 } & CLIL & Non-CLIL \\
\hline 33. I would like to speak and use Basque fluently and effortlessly. & 3.74 & 3.68 \\
35. I think Basque is a nice language. & 3.83 & 3.76 \\
37. It is rather easy for me to learn languages. & 2.99 & 2.95 \\
39. I like learning Basque. & 3.71 & 3.63 \\
41. I would like to continue to learn Basque. & 3.80 & 3.69 \\
43. I find Basque as a second language lessons really boring. & 1.50 & 1.54 \\
46. I find Basque CLIL lessons really boring. & 1.74 & 1.76 \\
48. I think I am good at Basque. & 3.38 & 3.37 \\
50. Speaking/knowing Basque is essential for one to find a job. & 3.01 & 2.97 \\
53. I think CLIL lessons in Basque are fun. & 3.33 & 3.24 \\
55. I think Basque as a second language lessons are fun. & 3.48 & 3.45 \\
58. I think Basque will be useful for me when I grow up. & 3.27 & 3.23 \\
59. It is difficult for me to learn languages. & 2.23 & 2.34 \\
63. Learning Basque is easy. & 3.28 & 3.24 \\
65. I feel confident when using Basque. & 3.53 & 3.41 \\
& 3.12 & 3.08 \\
\hline
\end{tabular}

Values: 4: 'I fully agree'; 3: 'I somewhat agree'; 2: 'I somewhat disagree'; 1: 'I fully disagree'. 